\title{
Volumetric and economic evaluation of Eucalyptus spp. clones in high forest, coppice and native vegetation systems at the Gypsum Pole of Araripe - PE
}

\author{
Avaliação volumétrica e econômica de clones de Eucalyptus spp. em sistemas \\ de alto fuste, talhadia e vegetação nativa no Polo gesseiro do Araripe - PE
}

\author{
Najara de Moura Fontenele ${ }^{1}$, Jose Antonio Aleixo da Silva ${ }^{2}$, Rinaldo Luiz Caraciolo Ferreira ${ }^{2}$, \\ Rute Berger ${ }^{2}$, Fenando Henrique de Lima Gadelha ${ }^{3}$ e Mariel Ouorou Ganni Guera ${ }^{4}$
}

\begin{abstract}
Resumo
Objetivou-se neste trabalho realizar uma análise silvicultural de clones de eucaliptos nos sistemas de condução por alto fuste e talhadia e a vegetação nativa, definindo o melhor sistema; recomendar o clone de maior rendimento volumétrico; definir a Idade de Rotação Técnica e realizar análise econômica da talhadia; comparar fontes energéticas utilizadas na região e indicar a mais economicamente viável. O experimento foi conduzido na Estação Experimental do Araripe do Instituto Agronômico de Pernambuco (IPA), em Araripina - PE. Foram testados 15 clones de híbridos de eucaliptos (tratamentos) com 4 repetições em espaçamento de $3 \mathrm{~m} \times 2 \mathrm{~m}$, com 25 plantas na área útil da parcela que foram também comparados com a vegetação nativa. Todas as árvores foram cubadas rigorosamente pela fórmula de Smalian. O experimento foi instalado em delineamento inteiramente casualizado. As médias dos tratamentos foram comparadas pelo teste de Scott-Knott. O clone C39 (Híbrido de E. urophylla) apresentou maior produtividade estimada em 72,99 m/ ha/ano em talhadia, sendo assim inferior, pois quando o mesmo é utilizado em alto fuste obteve produtividade estimada em 166,17 m³/ha/ano em alto fuste. A idade de rotação técnica foi de 60 meses. Na análise financeira dos sistemas, foi observado que o alto fuste possui maior receita quando comparado a talhadia. $O$ Valor Presente Líquido (VPL) foi positivo em todas as taxas de juros consideradas. O clone C39 possui maior produtividade em menor tempo de rotação quando comparado aos planos de manejo florestal sustentado da Caatinga (PFMS). É viável economicamente e ambientalmente, pois seu uso como fonte energética diminui a pressão antrópica sobre vegetação nativa para o mesmo fim, atenuando assim sua devastação.
\end{abstract}

Palavras-chave: Crescimento florestal, matriz energética, análise financeira.

\begin{abstract}
The objective of this work was to perform a silvicultural analysis of eucalyptus clones in the high forest, coppice, and native vegetation conduction systems to establish the best system; to recommend the clone of highest volumetric yield; to determine the Technical Rotation Age and perform an economic analysis of the coppice; to compare energy sources used in the region and indicate the most viable economically. The experiment was conducted at the Araripe Experimental Station of the Agronomic Institute of Pernambuco (IPA), in Araripina - PE. Fifteen Eucalyptus hybrids (treatments) clones were tested with 4 repetitions in a space of $3 \mathrm{~m} \times 2 \mathrm{~m}$, with 25 plants in the plot's useful area, which were also compared with native vegetation. All trees were rigorously measured by the Smalian formula. The experiment was performed in a completely randomized design. Treatment means were compared using the Scott-Knott test. Clone C39 (Hybrid of E. urophylla) presented the highest productivity, estimated at $72.99 \mathrm{~m}^{3} / \mathrm{ha} / \mathrm{year}$ in coppice, therefore lower, because when it is used in high forest, it obtained an estimated productivity of $166.17 \mathrm{~m}^{3} / \mathrm{ha} /$ year. The Technical Rotation Age was 60 months. In the financial analysis of the systems, it was observed that high forest provides the highest revenue when compared with coppice. The Net Present Value (NPV) was positive in all interest rates considered. Clone C39 provides higher productivity in a shorter rotation time when compared with the Sustainable Forest Management Plans (PFMS) of the Caatinga. It is economically and environmentally viable, since its use as an energy source reduces the anthropic pressure on native vegetation for the same purpose, thus reducing its devastation.
\end{abstract}

Keywords: Forest growth, energetic source, financial analysis.

\footnotetext{
${ }^{1}$ Master in Forest Sciences. UFRPE - Federal Rural University of Pernambuco. Rua Manoel de Medeiros, s/n, Dois Irmãos - 52171-900 - Recife, PE, Brazil. E-mail: najara.15@hotmail.com.

${ }^{2}$ Professor. UFRPE - Federal Rural University of Pernambuco. Rua Manoel de Medeiros, s/n, Dois Irmãos - 52171-900 Recife, PE, Brazil. E-mail: jaaleixo@gmail.com; rinaldo@dcfl.ufrpe.br; rute.berger@ufrpe.br.

${ }^{3}$ Associate Professor. IFPE - Federal Institute of Education, Science and Technology of Pernambuco. Rua Sebastião Joventino, s/n ${ }^{\circ}$, - 54.510-110, Cabo de Santo Agostinho, PE, Brazil. E-mail: fhlg_9@hotmail.com.

${ }^{4}$ Doctor in Forest Sciences. UFRPE - Federal Rural University of Pernambuco. Rua Manoel de Medeiros, s/n, Dois Irmãos - 52171-900 - Recife, PE, Brazil. E-mail: gueraforest@gmail.com.
}

Sci. For., Piracicaba, v. 46, n. 117, p. 77-86, mar. 2018 DOI: dx.doi.org/10.18671/scifor.v46n117.07 
Fontenele et al. - Volumetric and economic evaluation of Eucalyptus spp. clones in

high forest, coppice and native vegetation systems at the Gypsum Pole of Araripe - PE.

\section{INTRODUCTION}

The Gypsum Pole of Araripe region is considered an area of anthropic pressure on forest resources, as it uses firewood as the main energy source of the gypsum industry. Only 5\% of this wood comes from sustainable forest management plans (PFMS) registered in the region, what leads to a degradation of the local vegetation due to its illegal removal (BRASIL, 2007; ROCHA, 2012; SILVA, 2008-2009).

An alternative to reduce this degradation and meet the energy demand is the introduction of fast-growing forest stands with species adapted to the region, which have higher volumetric growth than the native ones, such as the case of the Eucalyptus genus with approximately 740 species with several purposes: firewood, charcoal, paper, pulp, essential oils, among others (VALE et al, 2014).

In forest stands, there are the high-forest, and coppice conduction systems, that, after clear cut the more vigorous sprouts on the remaining teak stumps are conducted (FERRARI et al., 2005).

In coppice, a reduction in productivity is observed relative to high forest, however, by means of management it is possible to achieve a similar or greater productivity, if the resources that encourage growth are maintained and expanded after the clear cut of the first rotation (FARIA et al., 2002; FREITAG, 2013).

Coppice conduction presents a further reduction in costs with the production and maintenance of the stands, since it does not involve the costs relating to a new planting. However, to maintain the productivity of the high forest, higher fertilizing costs are necessary. Therefore, it is necessary to analyze the productivity and costs ratio in an economic basis in deciding the most viable conduction system for the region.

In addition, the definition of the silvicultural rotation age is essential for determining the best period to perform the clear cut when the objective of management is to achieve maximum production per unit of area. In this case, the age of maximum Mean Annual Increment (MAI) results in an average annual volume greater than the annual volume that would be obtained if the stand was cut in any other age (RODRIGUEZ et al., 1997).

In order to obtain alternative to meet the energy demand of the gypsum industry in the Gypsum Pole of Araripe, this work aims to perform a silvicultural analysis, with evaluation and comparison of production, growth and survival of eucalyptus clones in first and second rotation and the native vegetation, defining the most viable, determine the Technical Rotation Age, perform a financial analysis of the coppice and compare the energy sources used in the region and indicate the most viable economically.

\section{MATERIAL AND METHODS}

The study was conducted at the Experimental Station of the Agronomic Institute of Pernambuco (IPA) in the Chapada of Araripe, municipality of Araripina, with an average annual temperature of $24^{\circ} \mathrm{C}$ and average rainfall of $719 \mathrm{~mm}$ (APAC, 2014). In the past few years, rainfall has been lower, the data is obtained from rainfall recorders installed at IPA (Figure 1).

The high-forest experiment was implemented in March 2002, with 15 eucalyptus hybrids (treatment) clones in a completely randomized design, with 4 repetitions, in a total of 60 plots measuring $14 \mathrm{~m} \times 21 \mathrm{~m}$ in spacing of $3 \mathrm{~m} \times 2 \mathrm{~m}$, with 25 plants in the useful area per plot.

The clones are thus represented: C49 (E. tereticornis); C80, C315, C101, C78, C51 and C158 (E. urophylla x E. tereticornis); C156 (E. urophylla x E. tereticornis x E. pellita); C39, C41 and C33 (E. urophylla); C25, C31, C25 and C11 (E. brassiana).

The high-forest experiment was conducted until 84 months, with data available in Rocha (2012) and the second rotation was conducted by coppice with two trunks until 66 months and the clear cut was again performed. A high-forest data simulation was performed at 66 months, based on the Mean Annual Increment (MAI). The native vegetation data is available in FUPEF (2007).

The software used were ASSISTAT, R and Excel 2010 for data analysis and tabulation. The analysis of variance (ANOVA) was performed to ascertain whether there are differences among the measured variables. To verify the need for transforming the data, the Box e Cox (1962) transformations family was employed. The averages of the treatments were compared by the Scott-Knott test at a 5\% level of probability (SCOTT; KNOTT, 1974). 


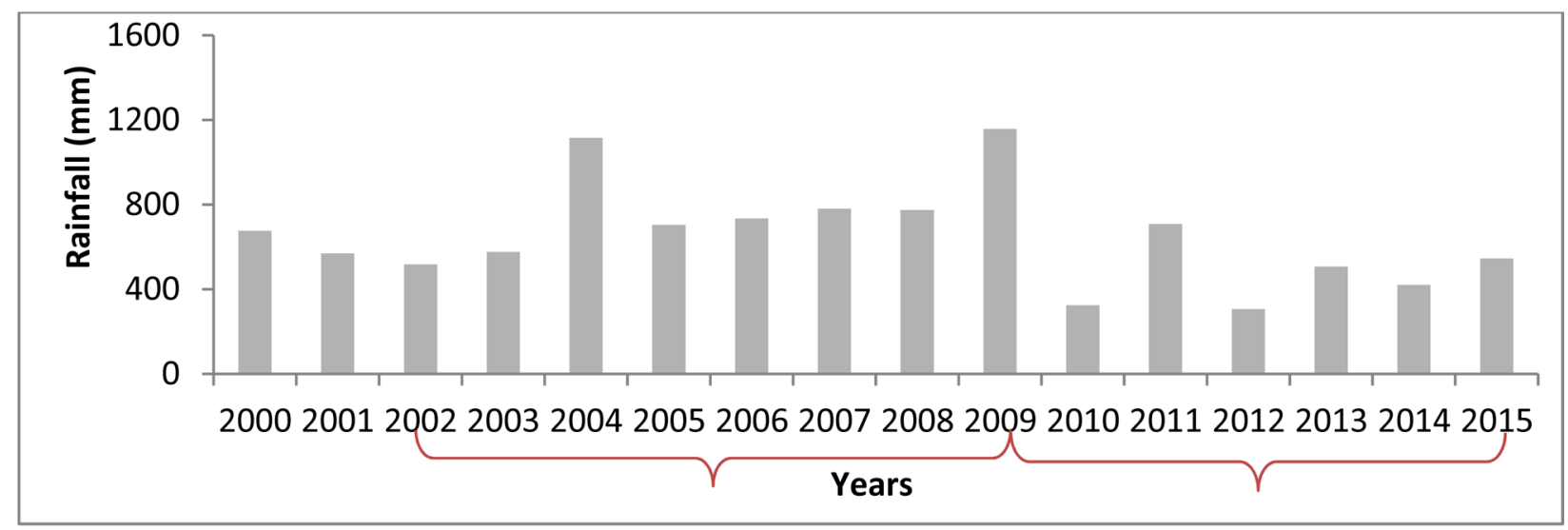

High Forest

Coppice

Source: Data collected at the IPA Experimental Station in Araripina, PE.

Figure 1. Average annual rainfall between 2000 and 2015 at the Experimental Station of the Agronomic Research Institute - IPA in Araripina.

Figura 1. Precipitação média anual entre 2000 e 2015 na Estação Experimental do Instituto de pesquisa agronômico - IPA em Araripina.

The trunks were strictly measured by the Smalian formula (MACHADO; FIGUEIREDO FILHO, 2003). The Technical Rotation Age (TRA) was defined in the intersection of the Mean Annual Increment (MAI) and Current Annual Increment (CAI) (RODRIGUEZ et al., 1997).

The volume data from CAI and MAI were adjusted as function of the age by the Schumacher (1939) model for the constructions of graphs for the definition of the TRA.

$$
V_{i}=\mathrm{e}^{\left(\beta_{0}+\beta_{1} \frac{1}{1_{\mathrm{i}}}\right)}+\varepsilon \mathrm{\varepsilon}
$$

Where: $V_{i}=$ tree volume $\mathrm{i} ; \mathrm{I}_{\mathrm{i}}=$ tree age $\mathrm{i} ; \mathrm{e}=$ exponential; $\beta_{\mathrm{o}}$ and $\beta_{1}=$ model parameters; $\varepsilon_{\mathrm{i}}=$ random error.

Being used for the financial analysis were the implementation and maintenance costs of the coppice and the revenue generated by the wood volume of the higher productivity clone. The parameter used was the Net Present Value (NPV) (SILVA, 2008-2009)

Interest rates of $6,8,10$ and $12 \%$ were considered. For the simulation and comparison of the MAIs between Caatinga and the eucalyptus clone of higher production, the maximum values found in the literature were used (FUPEF, 2007).

The Aliança Gypsum company provided data for each energy source and the value related to the production of one ton of gypsum.

\section{RESULTS AND DISCUSSION}

\section{Silvicultural analysis}

\section{Comparison of volumetric productivity}

The comparison of the Scott-Knott test result forming 3 groups for both coppice and high forest is observed in Table 1.

The logarithmic transformation was used to adjust the data, thus presenting a normal distribution with results from 0.96 to 0.11 for Shapiro-Wilk and 0.11 for p-value (Shapiro, 1965).

It should be noted that there was a drastic volumetric reduction in coppice, since only the C39, C101, C41 and C158 clones presented higher yields than the C3 clone, which had the lowest performance in the high-forest system. One factor that certainly influenced this decrease in productivity was the reduction in rainfall during the coppice rotation period.

It was observed that both at the first and the second rotation, the $\mathrm{C} 39$ clone is present in group "a", indicating its higher productivity in relation to the others. The C41 clone was classified in group " $b$ " under high forest, under coppice it was classified as group " $a$ ", wherein this difference in behavior may be associated to the fact that the clone lost less volume when compared to the others; this behavior was observed in several clones. 
Fontenele et al. - Volumetric and economic evaluation of Eucalyptus spp. clones in

high forest, coppice and native vegetation systems at the Gypsum Pole of Araripe - PE.

Table 1. Test result of the Scott-Knott test in terms of volume and a comparison between production and the loss of productivity of the Eucalyptus spp clones in first and second rotation at 66 months.

Tabela 1. Resultado do teste de Scott-Knott em termos de volume, e comparação da produção e da perda de produtividade dos clones de Eucalyptus spp. em primeira e segunda rotação aos 66 meses.

\begin{tabular}{llccc}
\hline Treatments & Clones & $\begin{array}{c}\text { Volume in first } \\
\text { rotation }\left(\mathbf{m}^{3} / \mathbf{h a}\right)\end{array}$ & $\begin{array}{c}\text { Volume in second } \\
\text { rotation }\left(\mathbf{m}^{3} / \mathbf{h a}\right)\end{array}$ & $\begin{array}{c}\text { Loss of production } \\
(\%)\end{array}$ \\
\hline 7 & C39 & $166.17 \mathrm{a}$ & $72.99 \mathrm{a}$ & 56 \\
4 & C101 & $110.34 \mathrm{c}$ & $70.85 \mathrm{a}$ & 36 \\
11 & C41 & $127.91 \mathrm{~b}$ & $57.68 \mathrm{a}$ & 55 \\
10 & C158 & $113.62 \mathrm{c}$ & $56.23 \mathrm{a}$ & 51 \\
2 & C80 & $99.94 \mathrm{c}$ & $51.37 \mathrm{a}$ & 49 \\
5 & C78 & $90.18 \mathrm{c}$ & $45.32 \mathrm{a}$ & 50 \\
9 & C51 & $110.43 \mathrm{c}$ & $46.09 \mathrm{a}$ & 58 \\
8 & C27 & $85.70 \mathrm{c}$ & $39.08 \mathrm{a}$ & 54 \\
3 & C315 & $98.74 \mathrm{c}$ & $37.52 \mathrm{a}$ & 62 \\
6 & C156 & $84.31 \mathrm{c}$ & $34.96 \mathrm{~b}$ & 59 \\
14 & C33 & $96.90 \mathrm{c}$ & $29.05 \mathrm{~b}$ & 70 \\
15 & C11 & $87.59 \mathrm{c}$ & $26.56 \mathrm{~b}$ & 70 \\
1 & C49 & $105.95 \mathrm{c}$ & $23.01 \mathrm{~b}$ & 78 \\
13 & C25 & $98.35 \mathrm{c}$ & $27.16 \mathrm{~b}$ & 72 \\
12 & C31 & $55.54 \mathrm{c}$ & $14.49 \mathrm{c}$ & 74 \\
\hline
\end{tabular}

The mean followed by the same letter do not statistically differ among themselves at the probability level of $5 \%$ with CV\% $=15.90$.

* Source: (ROCHA, 20I2)

** Actual volume obtained by measuring trees, established at 66 months of age after planting.

According to the results obtained, the least productive clone was C31 (E. brassiana) with 55.54 $\mathrm{m}^{3} /$ ha of natural crossing both in high forest and coppice with $14.49 \mathrm{~m}^{3} /$ ha. For being a clone of the same species, it is possible that this clone displays genotypic characteristics unfavorable to the climatic and edaphic conditions of the region, thus presenting disadvantages in competing with the other clones for nutrients and light.

Authors such as Moura et al., (1995) affirm that the E. brassiana species is originally found in Papua New Guinea with an average annual rainfall ranging from 1000 to $2500 \mathrm{~mm}$, growing in poorly drained soils on the margins of swamps, floodplains and in depressions; a different reality from the one in Araripina, which may have been a limiting factor for its sprouts.

The C27, C315, C156 and C33 clones obtained high survival rates, however, low yields with trees of lesser height and circumference.

From 2002 to 2009 (high forest), the average annual rainfall was $795.1 \mathrm{~mm}$, coppice, on the other hand, achieved an annual average of $567.1 \mathrm{~mm}$, a $29 \%$ reduction which may have influenced clone growth and productivity, since water availability is essential for the establishment and development of a forest planting.

Gonçalves et al., (2014), evaluating the influence of edaphoclimatic factors on the high-forest productivity and coppice of the E. grandis $x$ urophylla hybrid in Bahia, concluded that the eucalyptus sprout productivity is closely related to the rainfall regime, because in places where rainfall was greater, the coppice presented higher productivity than that of high forest.

According to the results obtained (Table 1), the C39 Clone (E. urophylla) is the most productive with a volume of $72.99 \mathrm{~m}^{3} /$ ha and, thus, it is the most suitable for the region, similar behavior in the first rotation in which it presented the highest productivity with $166.17 \mathrm{~m}^{3} / \mathrm{ha}$, thus demonstrating its adaptability in the region.

This higher productivity in volume by the clone in question can be attributed to the fact that the species features good growth, rooting, teak stump sprouting capacity and to be drought-tolerant, high resistance to diseases and plasticity of the species (VALLE, 2009; FONSECA et al., 2010; FREITAG, 2013).

\section{Comparison of survival and mortality}

The first and most productive group "a" is comprised of clones C39 and C101, with 87\% and 96.5\% survival, respectively (Table 2), indicating that these clones are more adapted to the region. The second group is comprised by clones: C41, C158, C51, C80, C78 with 68,5\%, 92,5\%, 91,0\%, $89 \%, 68 \%$ survival, respectively. The other clones of lesser results were grouped in "c". 
Table 2. Percentage of survival, mortality and results of the Scott-Knott test in terms of survival of the Eucalyptus spp clones in first and second rotation.

Tabela 2. Porcentagem de sobrevivência, mortalidade e resultado do teste de Scott-Knott em termos de sobrevivência, dos clones de Eucalyptus spp. em primeira e segunda rotação.

\begin{tabular}{llcc}
\hline Treatment & Clone & Survival (\%) High forest & Survival (\%) Coppice \\
\hline 7 & C39 & $89.0 \mathrm{a}$ & $87.0 \mathrm{a}$ \\
4 & C101 & $99.0 \mathrm{a}$ & $96.5 \mathrm{a}$ \\
11 & C41 & $72.0 \mathrm{a}$ & $68.5 \mathrm{~b}$ \\
10 & C158 & $91.0 \mathrm{a}$ & $92.5 \mathrm{a}$ \\
2 & C80 & $98.0 \mathrm{a}$ & $89.0 \mathrm{a}$ \\
5 & C78 & $72.0 \mathrm{a}$ & $69.0 \mathrm{~b}$ \\
9 & C51 & $95.0 \mathrm{a}$ & $91.0 \mathrm{a}$ \\
8 & C27 & $86.0 \mathrm{a}$ & $75.0 \mathrm{a}$ \\
3 & C315 & $85.0 \mathrm{a}$ & $81.5 \mathrm{a}$ \\
6 & C156 & $82.0 \mathrm{a}$ & $70.0 \mathrm{~b}$ \\
14 & C33 & $86.0 \mathrm{a}$ & $86.0 \mathrm{a}$ \\
15 & C11 & $51.0 \mathrm{~b}$ & $48.0 \mathrm{c}$ \\
1 & C49 & $85.0 \mathrm{a}$ & $64.0 \mathrm{~b}$ \\
13 & C25 & $79.0 \mathrm{a}$ & $53.5 \mathrm{c}$ \\
12 & C31 & $49.0 \mathrm{~b}$ & $30.5 \mathrm{c}$ \\
\hline
\end{tabular}

Averages followed by the same letter do not statistically differ among themselves at the probability level of $\mathrm{I} \%$ and $5 \%$ of probability with CV\% $=25.08$.

Having performed the test of normality, a normal distribution of data was observed. By means of the Scott-Knott test, high-forest clones were classified into two groups, in the coppice, three groups were formed.

When these rotations are compared, it is possible to observe that clone behavior was similar regarding survival (Table 2). Clones, such as C11 and C31 that, in the high-forest system were in group " $b$ ", were grouped as group " $c$ ", thus showing their lower survival percentage in both rotations. However, clones that in high forest were classified as group "a", such as, for example, C25 that in coppice was grouped as group " $\mathrm{c}$ ", whereby this behavior may be attributed to the drought that took place in the region, which was a limiting factor for regrowth.

Villas Bôas et al., (2009) evaluating species of Eucalyptus spp. in the first rotation, found survival rates between $50 \%$ and $85 \%$. It is important to note that the study was conducted in areas with rainfall exceeding $1200 \mathrm{~mm} /$ year, Marília - SP, different from Araripina - PE, whose average is of 719 mm (APAC, 2014).

Souza (2011), analyzing eight Eucalyptus spp. clones in second rotation, found survival rates ranging between $83 \%$ and $100 \%$. For Ferrari et al., (2005) who evaluated the regrowth conduction of three Eucalyptus spp. stands 60 days after the cut in Minas Gerais, two in the Zona da Mata and one in the Cerrado, obtained survival rates ranging between $25 \%$ and $100 \%$; it is possible then to say that the values for the survival rate found in the present study are satisfactory.

\section{Mean Annual Increment (MAI)}

ANOVA was performed for the MAI and significant differences were found; subsequently, with the Scott-Knott test, it was observed the formation of three groups with equal classification of the groups formed for volume (Table 3).

The differences in productivity between the rotations may be attributed to climatic factors, such as rainfall deficit, resulting in MAIs below the expected, which would be a value similar to high forest. When comparing these results with those found by Rocha (2012), one observes similar behavior with MAIs values between clone C39 and C31 in both rotations.

Resende et al., (2004) found MAI values for eucalyptus in Martinho Campos-MG, in first rotation that varied from $12.6 \mathrm{~m}^{3} /$ ha at 60 months to $47.4 \mathrm{~m}^{3} /$ ha at 48 months, which corroborates with the present study that found similar MAI results at 66 months in second rotation, thus evidencing that first and second rotation can obtain similar MAI, since age influences productivity.

Faria et al., (2002), evaluating the production and nutritional status of Eucalyptus grandis stands, in second rotation, obtained an MAI of $20.5 \mathrm{~m}^{3} /$ ha in first rotation and $12.9 \mathrm{~m}^{3} /$ ha in second rotation at 78 months. Thus, the present study obtained a similar MAI result with different ages. 
Fontenele et al. - Volumetric and economic evaluation of Eucalyptus spp. clones in

high forest, coppice and native vegetation systems at the Gypsum Pole of Araripe - PE.

Table 3. Mean Annual Increment and Scott-Knott test result of Eucalyptus spp. clones in the first and second rotation at 66 months.

Tabela 3. Incremento Médio Anual e resultado do teste de Scott-Knott dos clones de Eucalyptus spp. em primeira e segunda rotação aos 66 meses.

\begin{tabular}{llcc}
\hline Treatment & Clone & MAl $\left(\mathbf{m}^{3} / \mathbf{h a}\right)$ in first rotation & MAl $\left(\mathbf{m}^{3} / \mathbf{h a}\right)$ in second rotation \\
\hline 7 & C39 & 29.67 & $13.03 \mathrm{a}$ \\
4 & C101 & 19.70 & $12.65 \mathrm{a}$ \\
11 & C41 & 22.84 & $10.30 \mathrm{a}$ \\
10 & C158 & 20.29 & $10.04 \mathrm{a}$ \\
2 & C80 & 17.84 & $9.17 \mathrm{a}$ \\
5 & C78 & 16.10 & $8.09 \mathrm{a}$ \\
9 & C51 & 19.72 & $8.23 \mathrm{a}$ \\
8 & C27 & 15.30 & $6.98 \mathrm{a}$ \\
3 & C315 & 17.63 & $6.70 \mathrm{a}$ \\
6 & C156 & 15.05 & $6.24 \mathrm{~b}$ \\
14 & C33 & 17.30 & $5.18 \mathrm{~b}$ \\
15 & C11 & 15.64 & $4.74 \mathrm{~b}$ \\
1 & C49 & 18.91 & $4.10 \mathrm{~b}$ \\
13 & C25 & 17.56 & $4.85 \mathrm{~b}$ \\
12 & C31 & 9.91 & $2.58 \mathrm{c}$ \\
\hline
\end{tabular}

Averages followed by the same letter do not statistically differ among themselves at the probability level of $\mathrm{I} \%$ and $5 \%$ with $\mathrm{CV} \%=30.5 \mathrm{I}$.

\section{Technical Rotation Age (TRA)}

According to Figure 2, which are based on Current Annual Increment (CAI) and Mean Annual Increment (MAI) data, it is possible to observe the definition of the Technical Rotation Age - TRA.

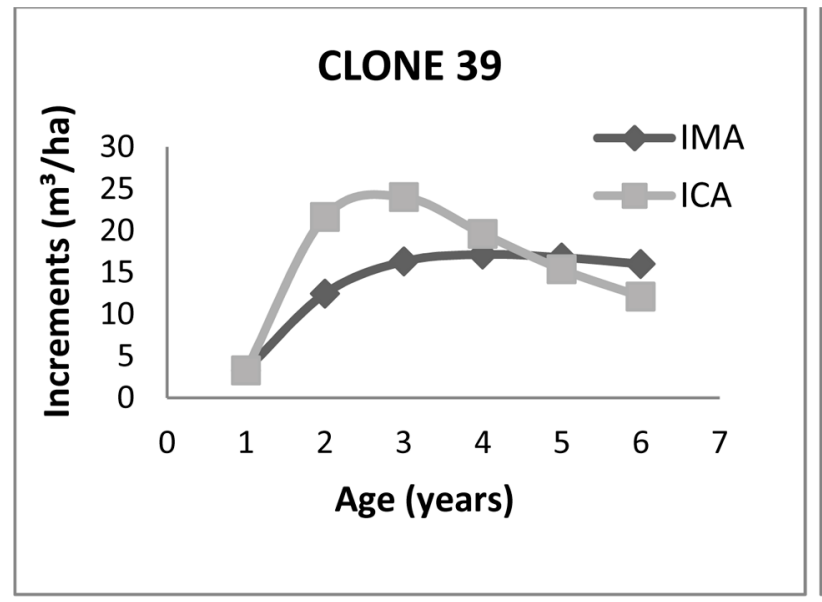

$V_{i}=e^{\left(5,23-4,04 I_{i}^{1}\right)} ; \mathrm{R}^{2}=95.86 \% ; \mathrm{S}_{\mathrm{yx}}=12.69 \%$
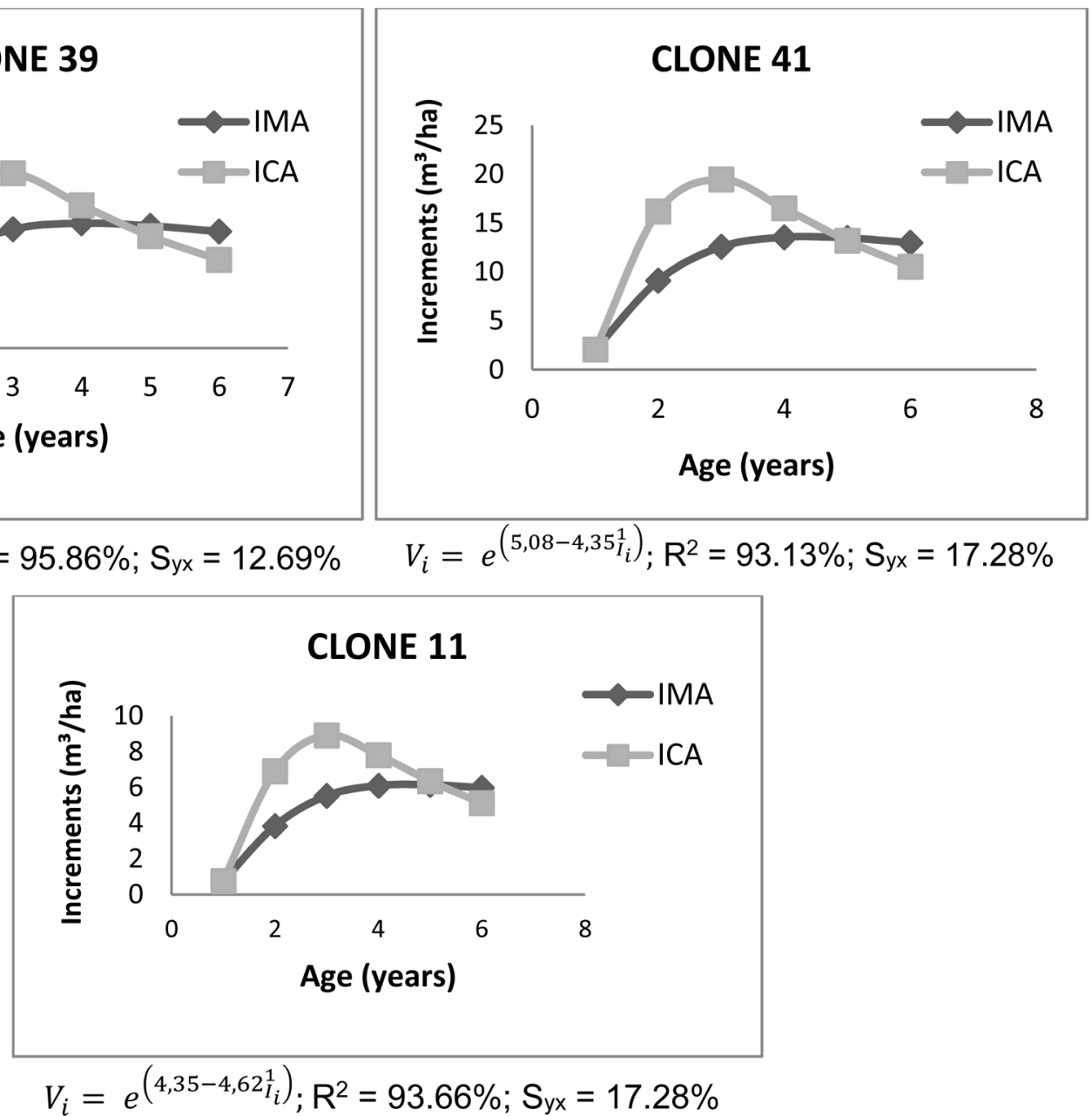

Figure 2. Current Annual Increment and Mean Annual Increment for clones C39 (E. urophylla), C41 (E. urophylla), C11 (E. brassiana)

Figura 2. Incremento corrente anual e incremento médio anual para os clones C39 (E. urophylla), C41 (E. urophylla), C11 (E. brassiana). 
However, it is necessary to observe not only the TRA to perform the cut of the stand. The plantings are usually carried out in the rainy season, which for the region in question is between the months of November to May. Therefore, it is important that upon calculating the TRA, the cutting season be taken into account to ensure that it does not take place in a dry period, which would compromise the sprouts of the following rotation. Hydric contribution is fundamental in the initial phase of planting.

Thus, the most suitable TRA is of 5 years (60 months) and at the beginning of the rainy season in the region, which is from November to May.

Rocha (2012) for the same clones, but in first rotation, found TRA between 6.5 and 7 years, wherein 7 years is more indicated because cutting season coincides with the rainy season. This early TRA ( 5 years) can be attributed to the low local productivity, the cutting season that was performed at 5 and a half years and even the drought that severely affected productivity.

Resende et al., (2004) using a growth and yield model for determining the rotation in eucalyptus stands in Martinho Campos-MG, also found an TRA of 5 years, thus corroborating with the present study.

In addition to the analysis of productivity in the rotation, in the definition of the Technical Rotation Age, it necessary to further observe the economic viability for the indication of the cutting season and the best conduction system for the region. According to Gadelha (2014) who conducted a financial analysis in the same area of study and concluded that the coppice has a lower cost and higher net profit, caused by the lack of deployment costs and further cost reductions with its conduction.

\section{Financial analysis}

According to the data used to perform the financial analysis with the deployment costs (Table 4), it was possible to compare high forest with coppice in financial terms and thus define the most viable.

Table 4. Costs and revenues from the implementation of the Eucalyptus spp clone experiment in high forest.

Tabela 4. Custos e receitas de implantação do experimento de clones de Eucalyptus spp. em alto fuste.

\begin{tabular}{|c|c|c|c|c|c|c|c|}
\hline Description & Year & Unit & Quantity & Unit value & Cost & Production (C39) & Revenue (R\$) \\
\hline Soil preparation & 1 & $\mathrm{~h} / \mathrm{m}$ & 4 & 80.00 & 320.00 & & \\
\hline Subsoiling & 1 & $\mathrm{~h} / \mathrm{m}$ & 1 & 60.00 & 60.00 & & \\
\hline Agricultural gypsum & 1 & $\mathrm{Kg}$ & 500 & 0.04 & 20.00 & & \\
\hline Chemical fertilizer & 1 & $\mathrm{Kg}$ & 250 & 1.00 & 250.00 & & \\
\hline Fertilizer application & 1 & $\mathrm{~h} / \mathrm{d}$ & 5 & 30.00 & 150.00 & & \\
\hline Seedlings & 1 & $\mathrm{R} \$$ & 1667 & 0.40 & 666.80 & & \\
\hline Seedling freight & 1 & 1 & 1667 & 0.25 & 416.75 & & \\
\hline Planting & 1 & $\mathrm{~h} / \mathrm{d}$ & 6.5 & 30.00 & 195.00 & & \\
\hline Ant control & $1-2$ & $\mathrm{~h} / \mathrm{d}$ & $6-6$ & 30.00 & 360.00 & & \\
\hline Manual weeding & $2-3$ & $\mathrm{~h} / \mathrm{d}$ & $5-5$ & 30.00 & 300.00 & & \\
\hline Maintenance & $1 \ldots 5$ & & 5 & 11.00 & 55.00 & & \\
\hline Production (ha) & 5 & $\operatorname{MAI}\left(\mathrm{m}^{3}\right)$ & 29.67 & & & & \\
\hline Firewood cutting & 5 & $\mathrm{~h} / \mathrm{m}^{3}$ & 166.17 & 12.00 & 1994.04 & 166.17 & \\
\hline \multicolumn{8}{|l|}{ Firewood value $\left(\mathrm{m}^{3}\right)$} \\
\hline Total $(\mathrm{R} \$)$ & & & & & 4787.59 & & \\
\hline \multirow[t]{3}{*}{ Net revenue $(\mathrm{R} \$)$} & & & & & & & 100.00 \\
\hline & & & & & & & 16617.00 \\
\hline & & & & & & & 11829.41 \\
\hline
\end{tabular}

Where: $\mathrm{h} / \mathrm{m}=$ machine hour, $\mathrm{h} / \mathrm{d}=$ man hour and $\mathrm{h} / \mathrm{m}^{3}=$ man per $\mathrm{m}^{3}$

High forest has higher costs as it includes initial deployment costs, such as soil preparation, subsoiling, agricultural gypsum, chemical fertilizer, fertilizer application, seedlings, seedling freight and planting, which are absent in the coppice.

The net revenue to produce a hectare of eucalyptus under coppice was $\mathrm{R} \$ 5.708,12$ with costs of only R \$ 1.590,00; however, due to its lower productivity when compared to high forest, it is less recommended. From the calculation of the NPV at different interest rates (Table 5), it is possible to observe in both conduction systems that the NPV was positive in all the interest rates and that even the coppice would be economically viable; high forest is still the most suitable conduction system to produce firewood in the region. 
Table 5. Net current value for clone C39 in coppice and high forest for different interest rates.

Tabela 5. Valor presente líquido para o clone C39 em talhadia e alto fuste para diferentes taxa de juros.

\begin{tabular}{lcccc}
\hline \multicolumn{5}{c}{ Interest Rate } \\
\hline NPV & $\mathbf{6 \%}$ & $\mathbf{8 \%}$ & $\mathbf{1 0 \%}$ & $\mathbf{1 2 \%}$ \\
\hline Coppice $(\mathrm{R} \$)$ & 4098.815 & 3692.697 & 3330.592 & 3007.12 \\
High forest $(\mathrm{R} \$)$ & 7419.814 & 6527.862 & 5730.807 & 5017.143 \\
\hline
\end{tabular}

Motta et al., (2010) analyzing the economic profitability of a eucalyptus plantation in high forest in São Paulo, found a NPV of R $\$ 18.579,52$ with an interest rate of $12 \%$ per year and at a second NPV scenario of R $\$ 8.076,00$ with an interest rate discount of $18 \%$ per year in relation to the deployment of a planted eucalyptus forest.

For the coppice, Rocha et al., (2015) performing an economic analysis of the deployment and conduction eucalyptus stands in Minas Gerais, found a NPV of R 782.91 for timber harvesting with individual producer, and for the hiring of a specialized company the NPV is of R $\$ 871.86$.

Gadelha (2014) analyzing the silvicultural and economic performance of eucalyptus hybrid clones planted under different handling schemes for energy purposes and in different ages for this same experiment, obtained as a result that clones C41 in the spacing of $2 \mathrm{~m} \times 2 \mathrm{~m}$ and $\mathrm{C} 39$ in $3 \mathrm{~m} \times$ $2 \mathrm{~m}$ in high forest, were the ones that presented higher NPV value and, thus, lower average production cost per $\mathrm{m}^{3}$ of wood. Clone $\mathrm{C} 39$, conducted in the coppice system, was the one that presented the higher NPV value and, consequently the lower average production cost of $\mathrm{m}^{3}$ of wood.

\section{Comparison of the economic yield of eucalyptus with the sustainable forest management plan of the Caatinga (SFMP)}

The costs and revenues related to the production of firewood in one hectare of SFMP to supply the industry of the Gypsum Pole of Araripe - PE. are based on the elaboration of the project (R\$ $50,00)$, maintenance $(\mathrm{R} \$ 80,00)$, production, firewood cutting ( $\mathrm{R} \$ 20,00)$, production of 75.04 $\mathrm{m}^{3} /$ ha with an MAI of $5.36 \mathrm{~m}^{3} /$ ha. The summary and the comparison between high forest, coppice and SFMP is represented in table 6.

Table 6. Comparison and summary of the economic analysis of eucalyptus under high forest, coppice and PFMS. Tabela 6. Comparação e resumo da análise econômica do eucalipto em alto fuste, talhadia e PFMS.

\begin{tabular}{lcccccc}
\hline Energy sources & $\begin{array}{c}\text { Rotation } \\
\text { (years) }\end{array}$ & $\begin{array}{c}\text { Production } \\
\left(\mathbf{m}^{\mathbf{3}} / \mathbf{h a}\right)\end{array}$ & $\begin{array}{c}\text { Firewood } \\
\left(\mathbf{R} \$ \mathbf{m} \mathbf{m}^{3}\right)\end{array}$ & $\begin{array}{c}\text { Revenue } \\
\text { (R\$/ha) }\end{array}$ & $\begin{array}{c}\text { Costs } \\
\text { (R\$/ha) }\end{array}$ & $\begin{array}{c}\text { Profit } \\
\text { (R\$/ha) }\end{array}$ \\
\hline Eucalyptus (high forest) & 5 & 166.17 & 100.00 & 16617.00 & 4787.59 & 11829.41 \\
Eucalyptus (coppice) & 5 & 72.99 & 100.00 & 7299.00 & 1590.00 & 5708.12 \\
PFMS & 14 & 75.04 & 100.00 & 7504.00 & 2670.80 & 4833.20 \\
\hline
\end{tabular}

It is possible to conclude that among the three energy sources analyzed, the eucalyptus conducted in the high-forest system is the most economically viable for the higher profit and shorter time, as well as environmentally by the benefits from the introduction of fast-growing forest stands and reduction of deforestation of native vegetation to meet the energy demands of the Gypsum Pole of Araripe.

\section{Cost of using energy sources}

In Table 7, values expressed in $\mathrm{R} \$$ are described and been provided by the Gesso Aliança company to produce one ton of gypsum, from main energy sources more frequently used in the industry of the Gypsum Pole of Araripe - PE.

Table 7. Actual values to produce one ton of gypsum from the main energy sources used in the industry of the Gypsum Pole of Araripe in Araripina - PE.

Tabela 7. Valores em real para produção de uma tonelada de gesso das principais fontes energéticas utilizadas na indústria do Polo Gesseiro do Araripe em Araripina - PE.

\begin{tabular}{lccc}
\hline Energy source & Price $(\mathbf{R} \$)$ & Consumption & Gypsum (R\$/ton) \\
\hline BPF oil & 1.20 & $37.00(\mathrm{l})$ & 44.40 \\
LPG gas & 3.80 & $22.00(\mathrm{~kg})$ & 83.60 \\
Coke & 0.49 & $38.00(\mathrm{~kg})$ & 18.62 \\
Caatinga firewood & 100.00 & $0.151 \mathrm{~m} 3$ & 15.10 \\
Eucalyptus firewood & 100.00 & $0.100 \mathrm{m3}$ & 10.00 \\
\hline
\end{tabular}


Faced with these values, it is possible to observe that eucalyptus is the energy source that has the lowest cost to produce one ton of gypsum, followed by Caatinga firewood and coke.

Eucalyptus has the lowest price for its use as an energy source, it is not pollutant in its production when compared to coke, being, therefore, considered the best choice for energy source, both economically and environmentally for supplying the gypsum industry in the Araripe region.

\section{CONCLUSIONS}

In the coppice system, the highest yield was obtained with clone C39 (E. urophylla hybrid) with $72.99 \mathrm{~m}^{3} /$ ha, lower than that obtained in first rotation; therefore, the most suitable is high forest that obtained higher yields.

The Technical Rotation Age of clone C39 in coppice was estimated at 5 years.

According to the financial analysis of the conduction systems, high forest even under longer rotation has higher revenue and volume when compared with coppice, that has higher revenue than native vegetation.

Among the energy sources used in the region, eucalyptus is the cheapest, costing $\mathrm{R} \$ 10.00$ per ton of gypsum produced. Eucalyptus spp. is economically and environmentally viable as its use as an energy source reduces the use of native vegetation for the same purpose, thus attenuating its devastation.

\section{REFERENCES}

APAC - AGÊNCIA PERNAMBUCANA DE ÁGUAS E CLIMA. Boletim do clima: síntese climática. Recife, v. 2, n. 6, p. 30, 2014.

BRASIL. Secretaria de Ciência, Tecnologia e Meio Ambiente. Região do Araripe Pernambuco: diagnóstico florestal. Brasília: Ministério do Meio Ambiente, 2007. 91 p.

BOX, G. E. P.; COX, D. R. An analysis of transformations. Journal of the Royal Statistical Society (Series B), London, v. 26, n. 2, p. 211-243, 1962.

FARIA, G. E.; BARROS, N. F.; NOVAIS, R. F.; LIMA, J. C.; TEIXEIRA, J. L. Produção e estado nutricional de povoamento de Eucalyptus grandis, em segunda rotação, em resposta a adubação potássica. Revista Árvore, Viçosa, v.26, n.5, p.577-584, 2002.

FERRARI, M. P.; FERREIRA, C. A.; SILVA, H. D. Condução de plantios de Eucalyptus em sistema de talhadia. Colombo: Embrapa Florestas, 2005. 28 p.( (Documentos, 104).

FONSECA, S.M.; RESENDE, M. D. V.; ALFENAS, A. C.; GUIMARÃES, L. M. S.; GRATTAPAGLIA, D. Manual prático de melhoramento genético do eucalipto. Viçosa: UFV, 2010. 200 p.FREITAG, A. S. Crescimento de brotações de um clone de Eucalyptus urophylla $\mathrm{x}$ Eucalyptus grandis em função da disponibilidade de nutrientes no solo e da aplicação de fitorreguladores na cepa. Tese (Doutorado em Recursos Florestais) Universidade de São Paulo, Escola Superior de Agricultura "Luiz de Queiroz", 2013, 82 p.

FUPEF - FINDAÇÃO DE PESQUISAS FLORESTAIS DO PARANÁ, Apoio técnico e institucional para o desenvolvimento do programa florestal da Chapada do Araripe: produto 2 - Diagnóstico. Curitiba: FUPEF, 2007, 203 p.

GADELHA, F. H. L; Desempenho silvicultural e avaliação econômica de clones híbridos de eucaliptos plantados em diferentes regimes de manejo para fins energéticos. 2014. 217 p. Tese (Doutorado em Ciências Florestais) - Universidade Federal Rural de Pernambuco, Recife, 2014.

GONÇALVES, J. L. M; ALVAREZ, C. A.; BEHILING, M.; ALVES, J. M.; PIZI, T.; ANGELI, A. Produtividade de plantações de eucalipto manejadas nos sistemas de alto fuste e talhadia, em função de fatores edafoclimáticos. Scientia Forestalis, Piracicaba, v. 42, n. 103, p. 411-419, 2014.

Sci. For., Piracicaba, v. 46, n. 117, p. 77-86, mar. 2018

DOI: dx.doi.org/10.18671/scifor.v46n117.07 
Fontenele et al. - Volumetric and economic evaluation of Eucalyptus spp. clones in

high forest, coppice and native vegetation systems at the Gypsum Pole of Araripe - PE.

MACHADO, S. A.; FIGUEIREDO FILHO, A. Dendrometria. Curitiba: A. Figueiredo Filho, 2003, 309 p.

MOTTA D., SILVA, W. F; DINIZ, E. N. Rentabilidade na Plantação de eucalipto. SEGET - SIMPÓSIO DE EXCELÊNCIA DE GESTÃO E TECNOLOGIA. 7., 2010, Resende. Anais... Rio de Janeiro: SEGET, 2010. Available: < https://www.aedb.br/seget/arquivos/artigos10/371_rentabilidade\%20na\%20plantacao\%20de\%20eucalipto. pdf >. Access in: June 102016.

MOURA, V. P. G.; OLIVEIRA, J. B.; VIEIRA, V. M.; Avaliação de procedências de Eucalyptus brassiana s. t. blake em Planaltina, Distrito Federal, área de Cerrado. IPEF, Piracicaba, n. 48/49, p.87-97, 1995.

RESENDE, R.R.; VALE, A. B.; SOARES, T. S.; SILVA, M. L.; COUTO, L. VALE. R. S. Emprego de um modelo de crescimento e produção para Determinação da rotação em povoamentos de eucalipto. Revista Árvore, Viçosa, v. 28, n. 2 , p. 219-225, 2004.

ROCHA, K. D. Produtividade volumétrica de clones de Eucalyptus spp. na Região do Polo Gesseiro do Araripe. Tese (Doutorado em Ciências Florestais) - Universidade Federal Rural de Pernambuco, Recife, 2012.

ROCHA, Q. S; SALES, H. L; CABACINHA, C. D. Implantação e condução de povoamentos de eucalipto em propriedades rurais na região de Montes Claros - MG: uma análise da viabilidade econômica. Caderno de Ciências Agrárias, Montes Claros, v. 7, n. 1, p. 75-88, 2015.

RODRIGUEZ, L. C. E; BUENO, A. R. S.; RODRIGUES, F. Rotações de eucaliptos mais longas: análise volumétrica e econômica. Scientia Forestalis, Piracicaba, n. 51, p. 15-28, 1997.

SCHUMACHER, F. X. A new growth curve and its application to timber yield studies. Journal Forestry. v. 37, p. 819-820, 1939.

SCOTT, A.J.; KNOTT, M. A cluster analysis method for grouping mean in the analysis of variance. Biometrics, Alexandria, v.30, p. 507-512, 1974.

SHAPIRO, S. S.; M. B. WILK. An Analysis of Variance Test for Normality (Complete Samples). Biometrika Trust, London, v. 52, n. 3/4, p. 591-609, 1965.

SILVA, J. A. A. Pontencialidades de florestas energéticas de Eucalyptus no Polo Gesseiro do Araripe - Pernambuco. Recife, Anais da Academia Pernambucana de Ciências Agronômicas, v. 5 e 6, p. 301-319, 2008-2009.

SOUZA, F. P. Crescimento e potencial energético de plantas intactas e de brotações de plantas jovens de clones de eucalipto. Dissertação (Mestrado em Ciência Florestal) - Universidade Federal de Viçosa, Viçosa, 2011, 67 p.

VALLE, M. L. A. Propriedades da madeira de eucalipto de primeira e segunda rotação, visando a sua utilização como madeira preservada. 2009. 96 p. Dissertação (Mestrado em Ciência Florestal) - Universidade Federal de Viçosa, Viçosa, 2009.

VALE, A. B.; MACHADO, C. C.; PIRES, J. M. M.; VILAR, M. B.; COSTA, C. B.; NACIF, A. P. Eucaliptocultura no Brasil - Silvicultura, Manejo e Ambiência. Viçosa: SIF, 2014. 551p.

VILAS BÔAS, O; MAX, J. C. M; MELO, A. C. G. Crescimento comparativo de espécies de Eucalyptus e Corymbia no município de Marília - SP. Revista do Instituto Florestal, São Paulo, v. 21, n. 1, p. 63-72, 2009.

Received on 06/24/2016

Accepted on 08/21/2017 